\title{
Program Agroschooling pada Siswa Sekolah Dasar SD 01 Manang untuk Meningkatkan Minat terhadap Bidang Pertanian
}

\author{
${ }^{1}$ Wahyu Adhi Saputro ${ }^{*},{ }^{2}$ Fachruddin Edi Nugroho Saputro \\ ${ }^{1}$ Program Studi Agribisnis, Fakultas Sains dan Teknologi, Universtas Duta Bangsa Surakarta, \\ ${ }^{2}$ Program Studi Rekam Medis, Fakultas Ilmu Kesehatan, Universtas Duta Bangsa Surakarta,
}

\author{
*Corresponding Author \\ Jl. Bhayangkara Tipes Serengan Kota Surakarta 57154 telp. (0271) 719552 \\ E-mail: wahyuadhi@udb.ac.id
}

Received: $\quad$ Revised: $\quad$ Accepted: Published:

25 April $2020 \quad 22$ May $2020 \quad 28$ May $2020 \quad 31$ Mei 2020

\begin{abstract}
Abstrak
Jumlah penduduk yang semakin meningkat diikuti dengan selarasnya kebutuhan pangan namun tidak diikuti dengan peningkatan sektor pertanian di Indonesia ditunjukkan dengan semakin berkurangnya minat anak muda di bidang pertanian. Permasalahan mengenai penurunan minat anak muda di pertanian hakikatnya menjadi perhatian khusus dari berbagai pihak karena menjadi faktor penghambat pertumbuhan pembangunan pertanian. SD Negri 01 Manang merupakan mitra yang tepat untuk diberikannya kurikulum pendidikan anak yang diselipkan arti penting pertanian sehingga dari masa kanak-kanak potensi pertanian untuk masa depan tertanam dalam pola pikir mereka. Solusi mengenai model edukasi pertanian sejak dini dirasa sangat tepat menarik minat anak-anak dan disesuaikan dengan kebutuhan, kemampuan dan kesenangan setiap anak sehingga dampaknya dapat meminimumkan dampak ketidaktertarikan generasi muda terhadap bidang pertanian. Program Agroschooling memiliki tujuan untuk mengenalkan kepada anak-anak sekolah dasar mengenai pentingnya dunia pertanian dan pengelolaan lingkungan alam sekitar. Metode yang diberikan dalam program agroschooling anak-anak SD menonton secara virtual video tentang pertanian, kemudian ditanyai dengan beberapa pertanyaan di kuesioner dengan bantuan mahasiswa mengenai cita-cita dan kesukaan di bidang pertanian. Acara dilanjutkan dengan penanaman tanaman di ikuti dengan pertanyaan kuesioner untuk menanyai apakah ada yang ingin berganti cita-cita setelah mengikuti program Agrochooling. Data-data tersebut di analisis menggunakan linkert dan diinputkan dalam rating scale. Selain itu digunakan analisis before dan after untuk melihat peningkatan anak-anak yang ingin bekerja di sektor pertanian sebelum dan sesudah diadakan program Agroshcooling. Survei awal membuktikan bahwa sebanyak 0\% dari siswa dan siswi SD yang bercita-cita ingin bekerja di sektor pertanian. Peningkatan persentase keinginan bekerja para siswa dan siswi di SD 01 Manang di bidang pertanian terjadi sebanyak 15,38\% setelah diadakannya program Agroschooling. Persepsi para siswa dan siswi terhadap kegiatan pengabdian kepada masyarakat mengenai agroschooling masuk ke dalam kategori baik. Harapannya akan adanya kelanjutan pengabdian dengan survey ketertarikan siswa terhadap pertanian.
\end{abstract}


Kata kunci: Pertanian; Agroschooling

\begin{abstract}
Increasing population followed by harmonious food needs but not followed by an increase in the agricultural sector in Indonesia is shown by the decreasing interest of young people in agriculture. The problem regarding the decline of young people's interest in agriculture is of particular concern to various parties because it is a factor inhibiting the growth of agricultural development. SD Negri 01 Manang is the right partner for child education curriculum which is tucked in the importance of agriculture so that from childhood childhood the potential of agriculture for the future is embedded in their mindset. The solution regarding the agricultural education model from the beginning is felt to be very appropriate to attract the interests of children and adapted to the needs, abilities and enjoyment of children so that the impact can minimize the impact of the young generation's disinterest in agriculture. The method given in the agroschooling program for elementary school children watched a virtual video about agriculture, then was asked a number of questions in the questionnaire with the help of students about their ideals and preferences in agriculture. The program was followed by planting plants followed by questionnaire questions to ask if anyone wanted to change their goals after joining the Agrochooling program. The data is analyzed using linkert and entered in the rating scale. Also used before and after analysis to see the increase in children who want to work in the agricultural sector before and after the Agroshcooling program was held. The Agroschooling Program aims to introduce elementary school children about the importance of agriculture and the management of the surrounding natural environment. Initial survey prove that as many as $0 \%$ of elementary school students want to work in the agricultural sector. The increase in the percentage of students wanting to work at SD 01 Manang in agriculture occurred as much as $15.38 \%$. The perception of students and students of community service activities regarding agroschooling into the good category. The hope is that there will be continued service by surveying student's interest in agriculture
\end{abstract}

Keywords: Agriculture; Agroschooling

\title{
PENDAHULUAN
}

Sekolah Dasar Negri 01 Manang merupakan sekolah dasar yang terletak di Dusun Babad Desa Manang Kecamatan Grogol Kabupaten Sukoharjo. Sekolah dasar ini dikelola dan dibiayai oleh pemerintah. Sekolah ini didirikan pada tanggal 1 Maret 1985 dengan SK pendirian sekolah 421,2/015/V/39/85. Data Rekap Per Tanggal 31 Oktober 2019 tercatat bahwa SDN 01 Manang memiliki total 168 siswa yang terdiri dari 85 siswa laki-laki dan 83 siswa perempuan (Kemendikbud, 2019). Di SDN 01 Manang ini memiliki 8 ruang kelas ditambah dengan 1 laboratorium dan 1 ruang perpustakaan.

Penurunan minat belajar generasi muda terhadap bidang ilmu pertanian khususnya di daerah yang pertaniannya maju menjadi masalah serius yang seharusnya mendapatkan perhatian khusus dari semua pihak. Selain itu disayangkan pula sikap orang tua yang cenderung mendoktrinasi kepada anak-anaknya agar tidak menjadi petani. Karena menurut mereka menjadi seorang petani seharusnya tidak membutuhkan pendidikan bahwa gelar sarjana. Dan makna petani selalu diidentikkan dengan kotor (berlumuran tanah), gaji yang sedikit, kurang bergengsi. Sehingga kondisi tersebut membuat generasi muda lebih tertarik di bidang non pertanian dibanding bidang pertanian. Persepsi bahwa sektor pertanian kurang menjanjikan masa depan masih sangat melekat dalam pikiran masyarakat khususnya anak muda. Selain itu pentingnya 
arti pertanian tidak diterapkan pada kurikulum pendidikan anak, sehingga dari masa kanakkanak potensi pertanian untuk masa depan tidak tertanam dalam pola pikir mereka. Cara pandang generasi muda yang salah akan arti penting pertanian akan menjadi ancaman bagi keberlanjutan pembangunan pertanian Indonesia. Kesalahan cara pandang tersebut harus dimatikan dari sekarang agar tidak lagi muncul generasi muda yang memiliki persepsi salah tentang pertanian. Mematikan persepsi tersebut dimulai dari anak-anak dimana pada masanya cepat menerima dan menyimpan segala sesuatu yang dapat mempengaruhi pembentukan karakternya.

Pendidikan adalah suatu proses pembaharuan makna pengalaman, hal ini mungkin akan terjadi di dalam pergaulan biasa atau pergaulan orang dewasa dengan orang muda, mungkin terjadi secara sengaja dan dilembagakan untuk menghasilkan kesinambungan sosial (Rinaldi, 2009). Proses ini melibatkan pengawasan dan perkembangan dari orang yang belum dewasa dan kelompok dimana dia hidup. Anak sangat menyenangi permainan di alam terbuka terlebih jika melakukan hal-hal baru yang belum pernah mereka lakukan. Kesenangan dari setiap anak ini dimanfaatkan sebagai alat mempermudah penyaluran pola piker yang benar tentang arti penting pertanian. Dengan demikian kehidupan sehari-hari anak dan lingkungan sekitas dapat membentuk kepribadiannya (Kanisius, Iman, 2004). Kehidupan di masa kanak-kanak didominasi aktivitas bermain. Bermain bagi anak-anak merupakan jembatan untuk mengembangkan kemampuan kognitif, bahsa, ruang spasial dan lingkungan sekitar (Palenewen, 2012).

Kurikulum pendidikan anak diberbagai level sekolah telah mengalami pengembangan yang sangat pesat. Saat ini sistem belajar dikelas yang hanya membaca, menulis, dan mendengarkan guru dirasa sudah tidak efektif lagi. Berbagai aplikasi seperti yang dapat diunduh menggunakan gadget adalah salah satunya. Akan tetapi jika tidak dikontrol atau dalam bimibingan orang tua maka terkadang anak-anak lebih suka bermain game seperti $P U B G$ (https://www.pubg.com/), Mobile Legend (https://m.mobilelegends.com/), dan lainnya sehingga membuat kecanduan akan game ketimbang aplikasi pembelajaran yang diberikan. Sehingga ketertarikan tersebut membuat anak-anak tidak peka terhadap keadaan atau kondisi lingkungan disekitar karena lebih fokus kepada game tersebut. Menurunnya minat masyarakat khususnya generasi muda terhadap pertanian dikarenakan pada masa kanak-kanak kurang diperkenalkan dengan baik pentingnya arti pertanian bagi kelangsungan masa depan. Padahal pembentukan sinapsis banyak terjadi pada usia kanak-kanak dan pada masa kanak-kanak pula daya ingat serta pembentukan karakter sangat kuat. Oleh karena itu perlu adanya penanaman ilmu pertanian sejak dini.

Kondisi terkini dari SDN 01 Manang terlihat bahwa tanaman belum tertata secara rapi dan baik. Belum adanya kurikulum yang menanamkan ilmu pertanian sejak dini dan belum adanya kebun bibit sekolah. Kebun bibit sekolah ini nantinya menjadi cikal bakal ketertarikan siswa terhadap pertanian khususnya terhadap tanaman yang sudah langsung bisa dipanen sehingga harapannya siswa bisa memanen sendiri dari tanaman yang ditanam. Pemanfaatan lingkungan sekolah sebagai sumber belajar dimanfaatkan jika relevan dengan proses pembelajaran. Untuk pembelajaran IPA, tumbuhan di taman dan kebun sekolah dapat dijadikan sebagai sumber pembelajaran. Lingkungan sebagai sumber belajar dapat dimanfaatkan untuk melihat kondisi fisik lingkungan sekitar dengan segala permasalahannya. Misalnya mengangkat tema pencemaran air, sampah, sungai, danau, gunung, hutan, dan kejadian sosial yang membawa pengaruh bagi kehidupan manusia (Komalasari, 2013).

Pada analisis situasi sudah dijelaskan beberapa masalah yang ada di kalangan anak-anak khususnya di SDN 01 Manang yang menjadikan latar belakang mengapa perlunya diadakan pengabdian kepada masyarakat, permasalahan yang teridentifikasi ada tiga yang pertama Menurunnya ketertarikan anak-anak di bidang pertanian. Kedua mengenai kecanduan anak-anak pada permainan yang ada di gadget sehingga kurang peka terhadap lingkungan sekitar. Ketiga 
Penataan dan perawatan serta manjemen kelola tanaman di area pekarangan sekolah yang kurang baik. Pengabdian ini juga ingin melihat minat dan keinginan ketika besar nanti siwa ingin menjalani profesi apa sebelum diberikannya wawasan pengabdian dan sesudah diberikan wawasan bidang pertaniana saat pengabdian berlangsung.

\section{METODE}

Metode yang digunakan dalam acara program agroschooling pada siswa sekolah dasar sd 01 manang untuk meningkatkan minat terhadap bidang pertanian menggunakan sampel responden para siswa kelas 4. Pemilihan anak-anak siswa kelas 4 SD dikarenakan menurut Badan Nasional Standar Pendidikan (2006) anak-anak mulai belajar ilmu pengetahuan alam (IPA) dimulai kelas 4 SD. Pertanian merupakan salah satu materi yang terdapat dalam pelajaran IPA. Selain hal tersebut dikarenakan siswa berada di pertengahan jenjang sekolah dasar sehingga harapannya dalam jangka panjang masih teringat dan tetap mempraktekkan apa yang diajarkan dalam pengabdian kepada masyarakat ini.

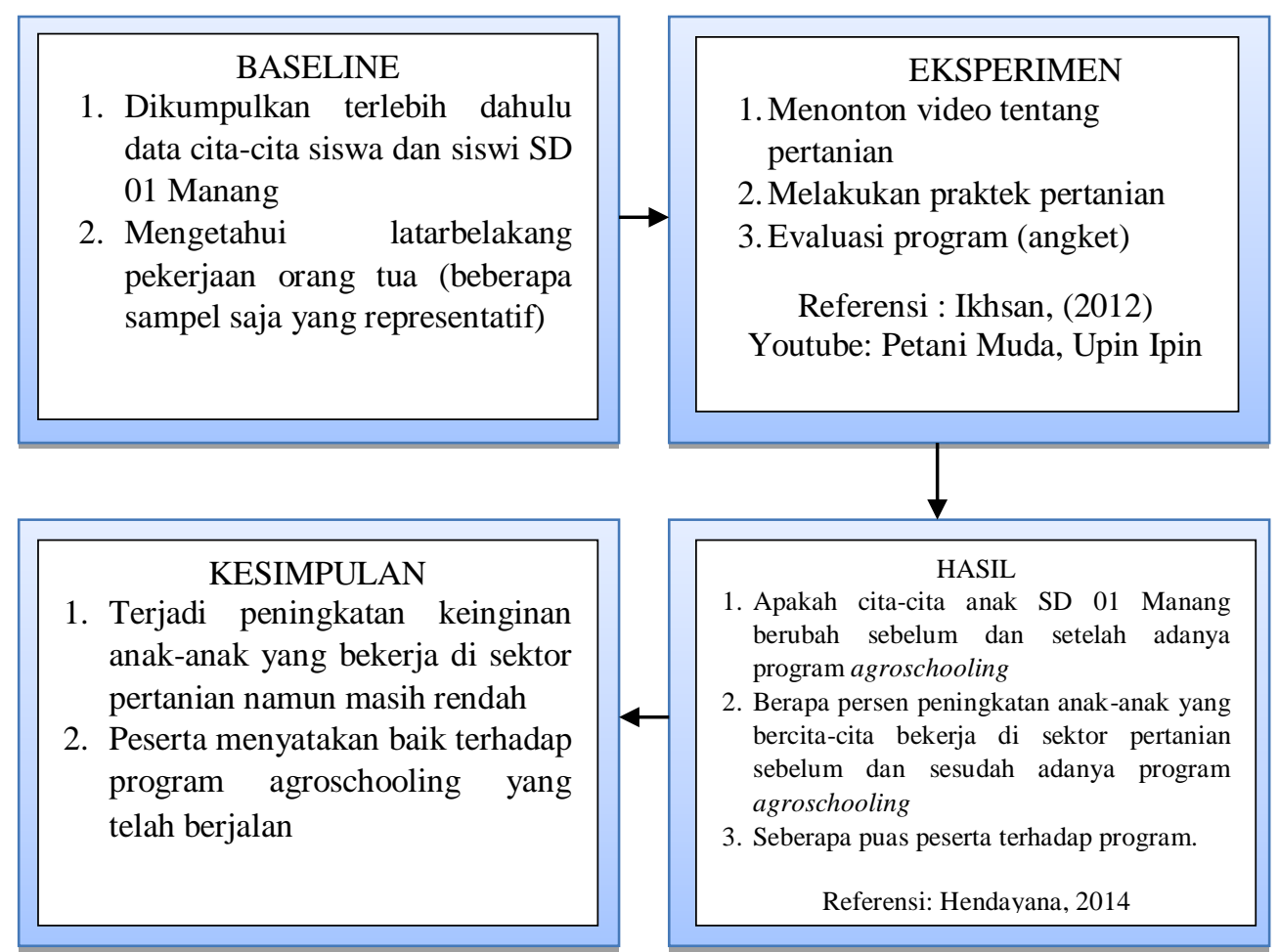

Gambar 1. Flow Chart Tahapan Pengabdian

Pada Gambar 1 dijelaskan mengenai tahapan-tahapan yang ada dalam pengabdian. Tahapan tersebut meliputi baseline, eksperimen, hasil dan kesimpulan. Baseline diperlukan untuk menopang atau mendukung program pengabdian sehingga pada hasil akhir dapat dilihat perubahan apa saja yang terjadi terhadap program yang diberikan. Lebih jelasnya akan diberikan gambaran tahap demi tahap di paragraph-paragraf selanjutnya. 


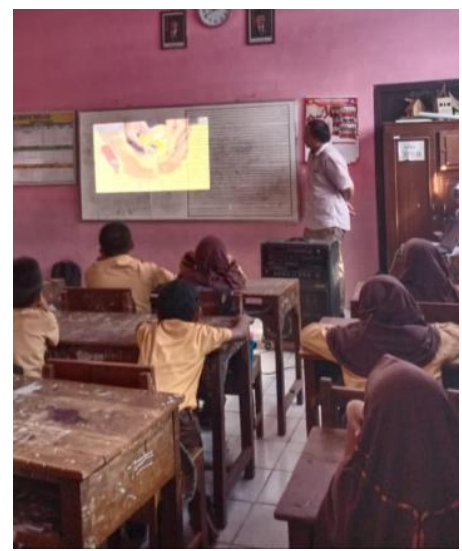

Gambar 2. Tahap 1 Pengabdian

Langkah pertama para siswa SD 01 Manang dikumpulkan di kelas, kemudian di presensi setiap siswa yang hadir di kelas tersebut. Pada awal acara ditanya apa cita dari masing-masing siswa untuk melihat apakah benar minat terhadap bidang pertanian sangat rendah atau tidak. Jika sudah dilanjutkan dengan agenda awal yaitu menonton film kartun dan role model petani modern di Jepang yang mengulas tentang pertanian dari menyiapkan sarana produksi pertanian, proses budidaya hingga cara memanen. Film tersebut diambil dari youtube.Terdapat dua film yang ditonton diantaranya adalah:

1. Upin Ipin tentang Berkebun (https://www.youtube.com/watch?v=ZEo1x5jAXVM) (Qasdina, 2013)

2. Petani Muda (Erick Yuliantoro) tentang review mesin tanam (https://www.youtube.com/watch?v=sbAXQ8G1 YS8) (Muda, 2017)

Adanya dua film tersebut diharapkan merubah mindset anak anak terhadap bidang pertanian yang kotor, berlumpur, tidak keren dan uang sedikit. Role model yang di tampilkan adalah mas Erick Yuliantoro yang berada di Jepang dan bertani di sana menggunakan alat-alat mesin pertanian seperti transplanter, combine dan drone untuk menyiram tanaman. Dengan begitu anak-anak bisa membayangkan bahwa pertanian modern di jaman sekarang sudah canggih dan keren. Harapan lainnya dengan hal tersebut sebelum melakukan praktik anak-anak sudah terbayang dahulu acara yang akan dihadapinya. Melihat kartun mendukung pengaktifan mode visual anak-anak dalam menangkap materi yang akan diberikan.

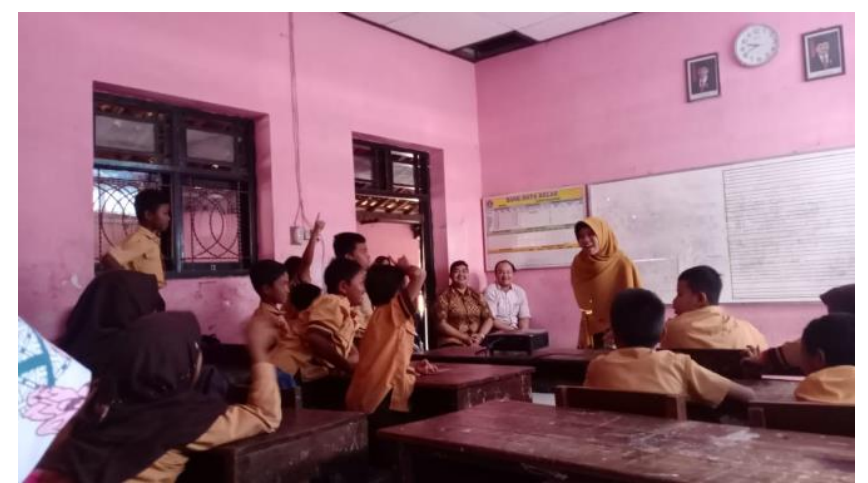

Gambar 3. Tahap 2 Pengabdian

Tahap selanjutnya setelah para siswa ditanya cita cita dan sudah melihat kartun tentang bidang pertanian adalah dengan bertanya kembali kepada siswa tentang apa saja yang baru saja 
dilihat. Anak-anak yang mampu meringkas dan menjawab pertanyaan dari narasumber akan mendapatkan hadiah menarik. Hal tersebut untuk memancing kreativitas siswa untuk mampu mengungkapkan apa mereka lihat sebelumnya. Harapannya juga mengasah otak para siswa dalam daya ingat masing masing siswa.

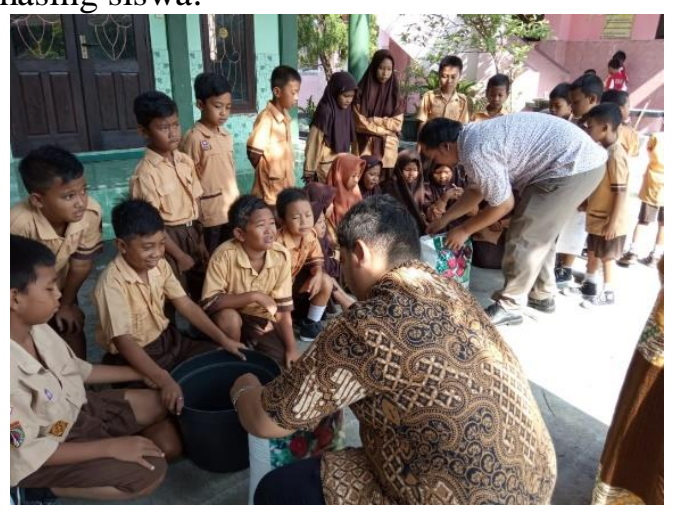

Gambar 4. Tahap 3 Pengabdian

Tahap ketiga para siswa dibawa ke luar kelas. Sarana yang digunakan adalah lapangan tempat upacara para siswa. Setelah dikumpulkan alat dan bahan di siapkan meliputi pot tanaman, tanaman jeruk dan jambu, media tanam (tanah, pupuk kandang, sekam bakar dan cocopit), dan air dalam sprayer kecil. Alat dan bahan tersebut sudah disiapkan terlebih dahulu oleh para mahasiswa yang membantu pengabdian. Langkah pertama siswa dijelaskan bagaimana cara menanam yang baik dan benar. Dijelaskan juga apa komposisi media tanam yang terdiri dari tanah, pupuk kandang dan sekam bakar dengan proporsi 1:1:1. Langkah pertama para siswa memasukkan tanaman dari polybag ke dalam pot dengan cara menepuknepuk polybag dan menggenggam tanaman masing masing dan dipindah ke pot. Media tanam diberikan ke dalam pot sampai pot penuh. Jika sudah tanaman kemudian disiram dengan air dan dipindahkan ke tepi lapangan. Setelah anak-anak menanam tanaman kemudian ditata dengan sebaik mungkin di pekarangan sekolah, terutama yang mendapatkan pencahayaan yang cukup. Pada hakikatnya taman sebagai elemen arsitektur sebagai pembatas gerak pandangan, penutup dan penghias dinding, pengarah, pembatas visual dan elemen estetis (Asikin, D., Handayani, RP., Mustikawati, 2016). Sehingga manajemen penataan yang baik akan memperindah pekarangan. Jika sudah para siswa diberikan waktu untuk cuci tangan hingga bersih dengan sabun. Apabila sudah selesai para siswa dikumpulkan kembali ke tengah lapangan. 


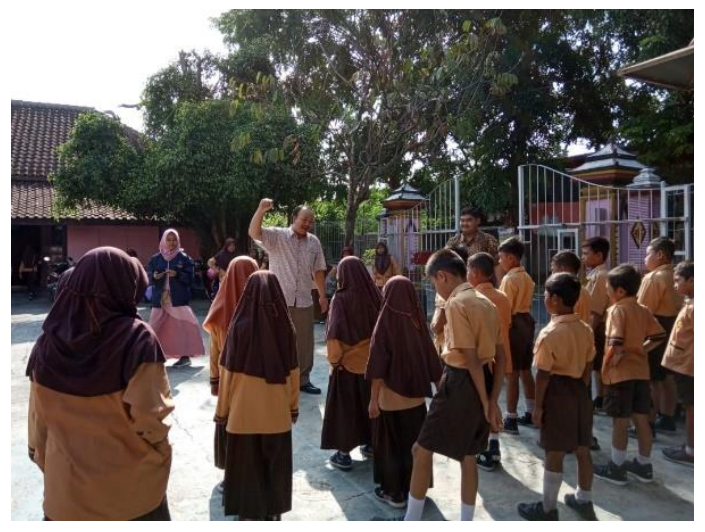

Gambar 5. Tahap 4 Pengabdian

Tahap terakhir ini ditujukan untuk narasumber bertanya kepada peserta apakah mereka puas mendapatkan program ini. Hal ini dibantu dengan para mahasiswa dalam mengumpulkan data sehingga peserta tidak kebingungan jika mengisi data sendirian. Selain itu ditanya pula apakah ada siswa yang ketika sudah besar nanti ingin bekerja di bidang pertanian atau tidak dihubungkan dengan kuesioner pada tahapan pertama. Apabila sudah selesai pengumpulan data para siswa diperbolehkan kembali ke kelas masing-masing untuk istirahat. Jika sudah selesai istirahat narasumber menutup acara kegiatan program pengabdian kepada masyarakat. Jika sudah terkumpul data before dan after mengenai cita-cita anak siswa dan siswi SD 01 Manang maka dapat dilihat selisih angka yang ingin bekerja di sektor pertanian sebelum dan sesudah diadakannya program agroschooling. Jika sudah kriteria tersebut dilihat seperti berikut (Hendayana, 2014):

1. Peningkatan $0-44,99 \%$ bernilai rendah

2. Peningkatan $45-64,99 \%$ bernilai sedang

3. Peningkatan $65-100$ bernilai tinggi

Metode yang digunakan untuk mengukur persepsi para siswa adalah Metode Skala Likert. Skala Likert merupakan metode pengukuran yang digunakan untuk mengukur sikap, pendapat dan persepsi seseorang atau kelompok orang tentang fenomena sosial (Sugiyono, 2012). Skala Likert adalah teknik skala non-komparatif dan unidimensional (hanya mengukur sifat tunggal) secara alami. Responden diminta untuk menunjukkan tingkat kesepakatan melalui pernyataan yang diberikan dengan cara skala ordinal. Dari dua pengertian diatas kita sudah bisa menyimpulkan bahwa skala likert merupakan metode perhitungan kuisioner yang dibagikan kepada responden untuk mengetahui skala sikap suatu objek tertentu. Bobot kuesioner memiliki skor 1-5 dimulai dari jawaban sangat tidak setuju hingga setuju. Untuk menghitung jumlah skor ideal (kriterium) dari seluruh item, digunakan rumus berikut:

\section{Skor Kriterium $=$ Nilai Skala $\times$ Jumlah Responden}

Selanjutnya, skor yang telah diperoleh kemudian dimasukkan kedalam rating scale. Rating scale berfungi untuk mengetahui hasil kuisioner dan wawancara secara umum dan keseluruhan yang didapat dari penilaian angket (kuisioner) dan wawancara (Hendayana, 2014). Berikut adalah daftar list pertanyaan yang diajukan untuk melihat persepsi siswa terhadap program agroschooling. 
1. Menurut anda bagaimana pelaksanaan program agroschooling?
a. Sangat baik
b. baik
c. Biasa saja
d. Kurang baik
e. Tidak baik

2. Menurut Anda bagaimana pemilihan waktu dan narasumber program agroschooling?
a. Sangat baik
b. baik
c. Biasa saja
d. Kurang baik
e. Tidak baik

3. Menurut Anda, bagaimana pemilihan tanaman dalam program agroschooling?
a. Sangat baik
b. baik
c. Biasa saja
d. Kurang baik
e. Tidak baik

4. Menurut Anda, bagaimana pemilihan film dalam program agroschooling?
a. Sangat baik
b. baik
c. Biasa saja
d. Kurang baik
e. Tidak baik

5. Menurut Anda, bagaimana pemilihan media tanam dalam program agroschooling?
a. Sangat baik
b. baik
c. Biasa saja
d. Kurang baik
e. Tidak baik

Dari kelima pertanyaan tersebut kemudian ditotal skor dan dicari tahu reratanya kemudian dimasukkan ke dalam standarisasi rating. Standarisasi rating tersebut dari total keseluruhan skor dan jumlah responen yaitu siswa dan siswi SD 01 Manang kelas 4 Sd. Berikut standarisasi rating:

1. Skor $0-26$ persepsi dinyatakan sangat kurang baik

2. Skor 27-52 persepsi dinyatakan kurang baik

3. Skor 53-78 persepsi dinyatakan cukup baik

4. Skor $79-104$ persepsi dinyatakan baik

5. Skor 105 hingga 130 persepsi dinyatakan sangat baik

\section{HASIL DAN PEMBAHASAN}

Dalam menanggapi persoalan yang telah diuraikan dengan sulitnya membangun dan mengembalikan citra pertanian yang baik bagi generasi muda ditambah dengan generasi muda yang terdoktrin bahwa sektor pertanian kurang menarik. Disisi lain anak-anak dimana pikiran mereka belum banyak asupan konsep, doktrin yang salah tentang pertanian selama ini. Kesempatan mengembalikan citra pertanian dapat dilakukan dengan membenamkan ilmu pertanian sejak dini. Pada masa kanak-kanak pula mereka memiliki memori dan daya ingat jangka panjang yang baik untuk menerima pemahaman pertanian secara benar, sehingga sejak dini mereka dapat berpikiran positif dan memiliki keinginan untuk memajukan pertanian ke 
depannya. Sehingga pemberian program Agroschooling anak-anak untuk meningkatkan minat terhadap bidang pertanian dapat dilakukan. Pengenalan pertanian diberikan dalam bentuk ekstrakurikuler untuk anak SD terbukti dapat meningkatkan persentase kesukaan siswa terhadap pertanian sebanyak $16 \%$ dan peningkatan persentase keinginan bekerja di bidang pertanian sebanyak 29\% (Rahmawatiningsih A., I.M.D. Prayoga, 2010). Aspek edukasi menyebutkan bahwa salah satu bentuk pembelajaran adalah memberikan pengalaman secara langsung, sehingga siswa dapat memahami konsep yang sedang dipelajari (Ramadhani, 2016).

Penyadaran generasi muda akan pentingnya sektor pertanian sepertinya sangat terlambat jika harus menunggu mereka untuk memilih kuliah di bidang disiplin ilmu pertanian. Sebaliknya, pendidikan dan pemahaman akan pentingnya sektor pertanian itu perlu diterapkan sejak usia dini, sejak sekolah dasar (Muharamsyah, 2013). Pada dasarnya manusia selalu melakukan kegiatan bermain pada masa anak-anak, dikarenakan mampu membangkitkan sisi kognitif, sosial, fisik, serta kemampuan emosional yang dibutuhkan pada saat dewasa (Baskara, 2011). Agroschooling bertujuan untuk mengenalkan dunia pertanian dan lingkungan alam sekitar kepada anak-anak khusunya anak-anak sekolah dasar. Agroschooling dikemas dalam bentuk kegiatan yang beda, tidak formal, kratif dan inovatif sehingga anak-anak bisa bermain sambil belajar (Ikhsan, 2012).

Tabel 1. Cita-Cita Siswa Sebelum dan Sesudah Kegiatan Pengabdian Kepada Masyarakat

\begin{tabular}{llcccc}
\hline No & Cita-Cita Pekerjaan & $\begin{array}{c}\text { Sebelum } \\
\text { Pengabdian } \\
\text { (orang) }\end{array}$ & $\begin{array}{c}\text { Persentase } \\
(\%)\end{array}$ & $\begin{array}{c}\text { Sesudah } \\
\text { Pengabdian } \\
\text { (orang) }\end{array}$ & $\begin{array}{c}\text { Persentase } \\
(\%)\end{array}$ \\
\hline 1 & Petani & 0 & 0 & 4 & 15,38 \\
\hline 2 & Guru & 3 & 8,33 & 3 & 8,33 \\
\hline 3 & Polisi dan TNI & 5 & 19,23 & 4 & 15,38 \\
\hline 4 & Dokter & 4 & 15,38 & 2 & 7,69 \\
\hline 5 & Pilot & 2 & 7,69 & 2 & 7,69 \\
\hline 6 & Youtuber & 2 & 7,69 & 2 & 7,69 \\
\hline 7 & Gamers & 3 & 8,33 & 3 & 8,33 \\
\hline 8 & Atlet & 7 & 26,93 & 6 & 23,07 \\
\hline
\end{tabular}

Pada tahapan awal sebelum pengabdian dilakukan anak-anak ditanyai mengenai cita-cita ketika nanti besar akan menjadi apa. Setelah itu dilakukan program agroschooling dengan tambahan menonton virtual mas Erick yang bekerja di Jepang sebagai petani menggunakan alat mesin pertanian modern seperti transplanter, combine dan drone. Setelah program pengabdian selesai anak-anak ditanyai kembali apakah cita-cita sebelumnya ingin berganti atau tidak. Anak adalah tunas bangsa, aset berharga yang merupakan bagian dari suatu negara (Hamadani, 2019). Oleh karena itu masa depan bangsa ini bergantung dengan anak-anak di zaman sekarang. Tabel 1 memperlihatkan cita-cita di masa mendatang para siswa dan siswi SD 01 Manang. Jika diperhatikan lebih detail kembali jawaban cita-cita anak anak SD 01 Manang sebelum adanya pengabdian bahwa paling banyak siswa menginginkan menjadi atlet sebanyak 7 siswa atau 26,93\%. Atlet yang dimaksudkan dalam tabel tersebut seperti sepak bola, bulu tangkis dan futsal. Hal tersebut dikarenakan memang era siswa tersebut berada pada era milenial dimana sukses tidak hanya berasal dari sesuatu pendidikan yang tinggi namun diperoleh dari hobi maupun bakat terpendam. Anak-anak ini tumbuh bersama zaman Cristiano Ronaldo, Lional Messi, dan Jojo sehingga pantas saja jika mereka mengidoalakn atlet dan menginginkan menjadi profesi tersebut ketika besar nanti. Pada urutan ke dua dan ketiga 
adalah profesi polisi, TNI serta dokter yang notabene merupakan cita-cita pada umumnya ketika anak kecil ditanya cita-citanya ketika besar nanti. Ada pula profesi guru dan pilot yang menjadi sasaran cita-cita siswa dan siswi SD 01 Manang. Hal tersebut dikarenakan profesi tersebut sangatlah keren dan menjanjikan dimata para siswa dan siswi. Bahkan ada pula yang menginginkan menjadi youtuber dan gamers ketika besar nanti. Hal ini tidak luput dari adanya gadget yang merupakan pegangan para siswa dan siswi milenial jaman sekarang. Mirisnya tidak ada satu pun siswa yang ingin menjadi petani maupun bekerja di bidang pertanian. Hal tersebut dikarenakan ketidak bolehan dari orang tua. Disamping itu petani dianggap merupakan pekerjaan yang menuntut baju kotor dan sugesti tidak akan kaya jika menjadi petani menurut anggapan siswa dan siswi SD 01 Manang. Ketertarikan para siswa terhadap bidang pertanian dapat dianggap 0\% sebelum adanya kegiatan pengabdian kepada masyarakat ini tentang "Program Agroschooling Pada Siswa Sekolah Dasar SD 01 Manang Untuk Meningkatkan Minat Terhadap Bidang Pertanian". Oleh karena itu pemilihan SD 01 Manang sebagai sasaran dalam program ini dirasa sangat tepat.

Tabel 1 juga mengungkapkan perubahan cita-cita para siswa dan siswi SD 01 Manang setelah mengikuti program pengabdian kepada masyarakat. Para siswa ditanamkan bahayanya ketika dimasa mudanya nanti tidak ada sama sekali orang yang ingin menggeluti bidang pertania. Terjadinya krisis pangan dimana-mana dan bumi semakin hancur dengan tidak terpedulikannya lingkungan sekitar. Dengan adanya program pengabdian ini siswa ditanamkan kembali bahwa petani tidak identik dengan kotor dan tidak kaya. Namun penggambaran bahwa petani modern kemana-mana menggunakan jas, dijadikan narasumber di berbagai wilayah, dimana hasil panen menumpuk dengan alat mesin pertanian yang canggih seperti transplanter, combine harvester bahkan drone untuk memupuk dan mengairi tanaman hal terebut terlihat pada role model Erick Yulianto sebagai petani modern yang bangga terhadap profesi pertanian di Jepang (youtuber petani muda). Serta para peserta disadarkan bahayanya jika Indonesia bukan negara agraris lagi dimulai dengan harga produk pangan semakin mahal dan langka. Dengan kesadaran juga memperbaiki lingkungan setidaknya dengan menanam memanfaatkan pekarangan sekitar bahkan memanen buah bisa dari pot. Adanya hal tersebut merubah mindset para siswa menjadikan ada beberapa yang ingin beralih profesi menjadi petani maju, pemilik lahan sawit yang luas dan penjual alat mesin pertanian berteknologi canggih. Kenaikan ini dari $0 \%$ hingga menjadi $15,35 \%$ berkat adanya program agroschooling.

Tabel 2. Rating Scale Persepsi Siswa Terhadap

Kegiatan Pengabdian Kepada Masyarakat

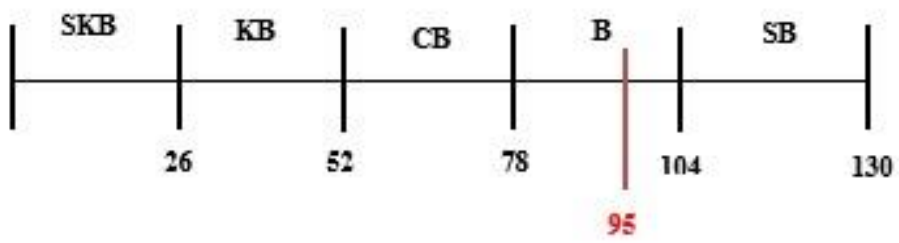

Berdasarkan Tabel 2 dapat dilihat bahwa rating scale persepsi siswa terhadap program kegiatan pengabdian kepada masyarakat tentang agroschooling ini memiliki skor 95. Skor tersebut masuk ke dalam kategori baik. Menurut para siswa agenda kegiatan ini membuka wawasan para siswa mengenai dunia pertanian sesungguhnya. Hal yang tadinya siswa hanya tahu bahwa petani itu membajak sawah, petani menggunakan caping dan kotor-kotoran menjadi petani modern yang keren. Dengan persepsi yang baik itu membuat kegiatan pengabdian ini menjadi contoh yang baik dalam pengenalan dunia pertanian kepada para siswa.

\section{KESIMPULAN}


Kegiatan pengabdian masyarakat yang dilakukan melalui metode agroschooling memberikan wawasan pentingnya pengetahuan tentang pertanian bagi para siswa sekolah dasar. Peningkatan persentase keinginan bekerja para siswa dan siswi di SD 01 Manang di bidang pertanian terjadi sebanyak $15,38 \%$ akan tetapi masih bernilai rendah. Persepsi para siswa dan siswi terhadap kegiatan pengabdian kepada masyarakat mengenai agroschooling masuk ke dalam kategori baik. Harapannya akan ada program pengabdian lanjutan mengenai ketertarikan siswa SD terhadap bidang pertanian.

\section{UCAPAN TERIMA KASIH}

Ucapan terima kasih diberikan kepada LPPM Universitas Duta Bangsa Surakarta yang telah memberikan izin pengabdian, serta kesediaan Kepala Sekolah SD 01 Manang Ibu Sri Endah Suraynti, S.Pd., M.Pd. dan para siswa menjadi peserta pada kegiatan pengabdian masyarakat ini.

\section{DAFTAR PUSTAKA}

Asikin, D., Handayani, RP., Mustikawati, T. (2016). Vertical Garden dan Hidroponik sebagai Elemen Arsitektural di Dalam dan di Luar Ruangan. Jurnal RUAS, 14(1), 34-42.

Badan Standar Nasional Pendidikan. (2006). Standar Isi. Jakarta: Badan Standar Nasional Pendidikan.

Baskara, M. (2011). Prinsip Pengendalian Perancangan Taman Bermain Anak di Ruang Publik. Jurnal Lanskap Indonesia, 3(1), 27-34.

Hamadani, A. (2019). Sekolah Alam: Alternatif Pendidikan Ramah Anak. Jurnal Harkat: Media Komunikasi Gender, 11(1), 86-95. https://doi.org/10.15408/harkat.v15i1.10433

Hendayana, R. (2014). Persepsi dan Adopsi Teknologi. Bogor: BPTP.

Ikhsan, G. (2012). Pendidikan Pertanian untuk Anakanak (Masih) Ada. Retrieved from http://edukasi.kompasiana.com/2012/12/29/pendi dikan-pertanian-untuk-anak-anakmasih-ada-514859.html

Kanisius, Iman, M. S. (2004). Pendidikan Partisipatif: Menimbang Konsep Fitrah dan Progresivisme John Dewey. Yogyakarta: Safiria Insani.

Kemendikbud. (2019). Sekolah Kita. Retrieved November 5, 2019, from Ditjen Dikti Depdiknas website: http://sekolah.data.kemdikbud.go.id/

Komalasari, K. (2013). Pembelajaran Kontekstul : Konsep dan Aplikasi. Bandung: PT Refika Adiatama.

Muda, P. (2017). Review Mesin Tanam. Retrieved from Youtube website: https://www.youtube.com/watch?v=sbAXQ8G1YS8

Muharamsyah, H. A. (2013). Pendidikan Pertanian, Celah Kecil Menuju Pembangunan yang Paripurna. International Association of Students in Agricultural and Related Sciences Local Committee Padjadjaran University. Padjadjaran: Padjadjaran University.

Palenewen, E. (2012). Pengembangan Model Pembelajaran Sains Melalui Bermain di Taman Kanak-Kanak. Jurnal Pendidikan Anak Usia Dini, 6(2).

Qasdina, D. (2013). Upin Ipin Berkebun. Retrieved from Youtube website: https://www.youtube.com/watch?v=ZEo1 x5jAXVM

Rahmawatiningsih A., I.M.D. Prayoga, N. P. W. Y. dan I. R. G. . T. (2010). Pemberian Ekstrakurikuler Pertanian Pada Siswa SD Di Desa Gunaksa Kabupaten Klungkung, Bali.

78 || Indonesian Journal of Community Services 
Jurnal IPTEKMA, 2(1), 1-4.

Ramadhani, W. S. (2016). Penerapan Pembelajaran Outdoor Learning Process (OLP) melalui Pemanfaatan Taman Sekolah sebagai Sumber Belajar Materi Klasifikasi Tumbuhan untuk Meningkatkan Hasil Belajar Siswa SMP. Jurnal Pendidikan Sains, 4(3), 1-7.

Rinaldi, I. (2009). Semua anak adalah Bintang. Jakarta: Kementrian Negara Pemuda dan Olahraga.

Sugiyono. (2012). Memahami Penelitian Kuantitatif. Bandung: Alfabeta. 